\title{
Sphagnum of the Pacific - a checklist
}

\author{
Ana Séneca ${ }^{1,2}$ and Lars Söderström ${ }^{1}$ \\ 1Department of Biology, Norwegian University of Science and Technology, N-7491 Trondheim, Norway \\ 2Department of Biology, Fac. Ciências Univ. Porto, Rua Campo Alegre, S/N, P- 4169-007 Porto, \\ Portugal
}

\begin{abstract}
Six species of Sphagnum are recorded for the Pacific and the origin of another, Sphagnum seemannii var. weberi supposed to come from Samoa, is questioned. Five species are rejected from the area due to recent taxonomic work. Sphagnum is only recorded from Fiji, Hawaii and New Caledonia, in addition to the questionable report from Samoa. The occurrences of Sphagnum are restricted to larger, older islands, with enough precipitation for a cloud forest type of vegetation and to those islands with high altitude crater lakes.
\end{abstract}

\section{Introduction}

The Sphagnum flora of the Pacific (sensu Brummitt 2001; Fig. 1) has not received much attention and many reports are old. The Hawaiian archipelago is the only relatively well studied area in the region with several recent bryological collections. New Caledonia has also received some recent attention while Fiji and Samoa (and most other islands in the Pacific) have received very little recent attention (cf. von Konrat et al. 2011).

The most recent list with distribution data including Sphagnum in the Pacific region is by Miller et al. (1978). They report eight taxa from Fiji, New Caledonia, Hawaii and Samoa and no Sphagna are recorded for any other islands in the Pacific. Of the taxa they report, we treat two in a narrower sense, S. compactum as S. wheeleri and S. cristatum as S. leratianum (both of which they had included as synonyms). We treat $S$. seemanii as a synonym of S. cuspidatum var. subrecurvum as per Eddy (1977) and question the origin of the original specimen of S. seemannii var. weberi. Finally we show that S. reichardtii never has been found in the region.

The Pacific Sphagnum taxa belong to four of the commonly accepted sections of the genus: sect. Sphagnum (S. leratianum, S. palustre, S. vitjianum), sect. Rigida (S. wheeleri), sect. Cuspidata (S. cuspidatum) and sect. Subsecunda (S. novo-caledoniae). According to the present taxonomic treatment four of the species are endemic: S. leratianum and S. novo-caledoniae to New Caledonia, S. vitjianum to Fiji and $S$. wheeleri to Hawaii. However, S. leratianum and S. vitjianum are probably conspecific with more widespread taxa (see notes below). 
Sphagnum peatlands in the Pacific are generally small compared to those in the boreal regions. With the exception of $S$. palustre in the Kohala mountains of Hawaii, where it forms mats in restricted montane bog communities, Sphagnum in this region generally grows immersed at the edge of lakes and in swamps (Bartram 1936) or on shaded to partially shaded moist rocks or silty soils, near streams in forested valleys (Iwatzuki 1986). In most cases Sphagnum occurs above $500 \mathrm{~m}$ altitude on the windward slopes where high orographic rainfall and low evapotranspiration rates prevents the occurrence of prolonged annual dry seasons (Whinam et al.2003). Sphagnum is absent from many islands of the Pacific due to their small area and lack of habitat. However, dispersal constraints can probably explain its absence from islands with adequate age, area, altitude and precipitation pattern as shown by the different Sphagnum floras of the islands of Maui and Hawaii (Karlin \& Andrus 1995). Combination of adequate altitude and rainfall exists in the Marquesas archipelago (islands of Hivoa and Fatuhuku) (Whittier 1973). Upolu (Samoa) and some of the crater lakes on Vanuatu islands also seem possible for Sphagnum due to their altitude, $\mathrm{pH}$, depth and surrounding vegetation, yet no species have been reported from there (Schabetsberger et al. 2009).

\section{Methodology and materials}

This checklist is arranged in alphabetic order. The list is in three parts, i) accepted reports, ii) doubtful reports, iii) excluded taxa. Finally, a list of all synonyms connected to reports from the Pacific is provided.

Each accepted taxon is qualified using a four level ranking system that indicates our level of confidence about a taxon's value. The coding convention is outlined in detail by von Konrat et al. (2010). Briefly,

? = problem with the taxon name (invalid, illegitimate, orphaned);

* = serious doubts about the value of the taxon;

** = probably a good taxon;

$* * *=$ accepted, a good taxon as currently understood.

We distinguish between first hand reports ("A report citing a specimen or an observation of material either in the field 'and then locality fairly exact' or among collected specimens") using bold font and second hand reports, ("Merely citing a locality that is not exact enough to be searched for the species, and not apparently based on a specimen that can be found"), using normal font (cf. von Konrat et al. 2010). The list includes all types coming from the Pacific region as defined by Brummitt (2001).

There are reports of Sphagnum from New Caledonia (NWC), both from the north and the south provinces (NWC-NO and NWC-SO); from Fiji (FIJ), Ovalau (FIJ-OV), Taveuni (FIJ-TA) and Viti-Levu (FIJ-VI); Hawaii (HAW), Hawaii I (HAW-HA), Maui (HAW-MA) and Oahu (HAW-OA); and from Samoa (SAM).

The occurrence of species in the Pacific and on each of the islands where Sphagnum has been recorded is shown in Table 1. Of the 12 taxa that have been reported to occur on these islands we accept six, question the occurrence of S. seemannii var. weberi on Samoa as well as its taxonomic value and reject five taxa from the area. See further notes under each taxon. 


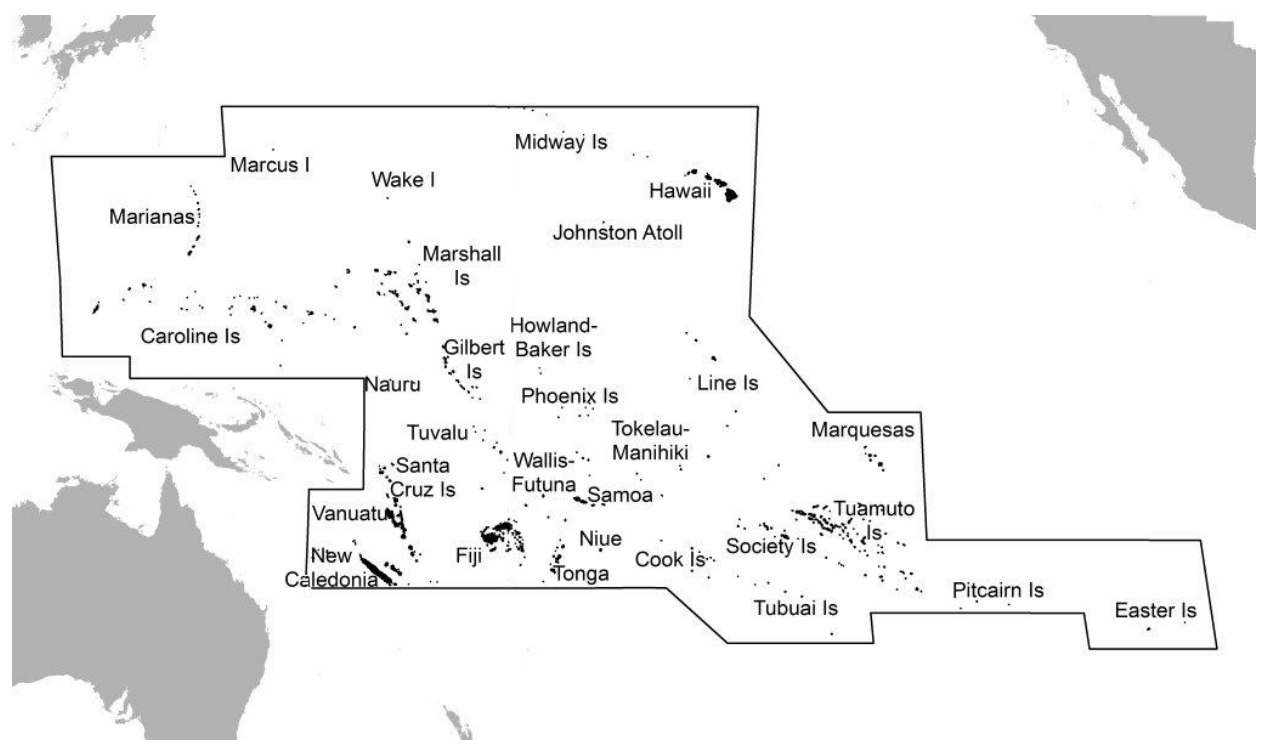

Fig. 1. Outline of the Pacific region as defined by Brummit et al. 2001.

Table 1. Sphagnum taxa reported from the Pacific Islands.

Abbreviations: FIJ - Fiji; OV - Ovalau; TA - Taveuni; VI - Viti Levu; HAW - Hawaii; HA - Hawaii Island; MA - Maui; OA - Oahu; NWC - New Caledonia; NO - New Caledonia North province; SO - New Caledonia South province. - rejected taxon; $\bullet, 0-$ first hand report (species and subtaxa, respectively); ? doubtful collection site; () - introduced.

\begin{tabular}{|c|c|c|c|c|c|c|c|c|c|c|c|c|c|}
\hline & \multirow{2}{*}{ Pacific } & \multicolumn{4}{|c|}{ Fiji } & \multicolumn{4}{|c|}{ Hawaii } & \multicolumn{3}{|c|}{ New Caledonia } & \multirow{2}{*}{$\begin{array}{l}\text { Samoa } \\
\text { SAM }\end{array}$} \\
\hline & & FIJ & $\mathrm{OV}$ & $\mathrm{TA}$ & VI & HAW & HA & MA & $\mathrm{OA}$ & NWC & $\mathrm{NO}$ & SO & \\
\hline S. compactum & - & & & & & - & & - & & & & & \\
\hline S. cristatum & - & & & & & & & & & - & & & \\
\hline S. cuspidatum & $\bullet$ & $\bullet$ & $\bullet$ & $\bullet$ & & - & & - & & - & & & - \\
\hline $\begin{array}{l}\text { - subsp. } \\
\text { cuspidatum }\end{array}$ & - & & & & & & & & & & & & \\
\hline $\begin{array}{l}\text {-subsp. } \\
\text { subrecurvum }\end{array}$ & 0 & 0 & 0 & $\circ$ & & & & & & & & & \\
\hline S. henryense & - & & & & & - & & & & & & & \\
\hline S. leratianum & $\bullet$ & & & & & & & & & & & $\bullet$ & \\
\hline $\begin{array}{l}\text { S. novo- } \\
\text { caledoniae }\end{array}$ & - & & & & & & & & & - & - & - & \\
\hline S. palustre & - & - & & & - & - & - & & $(\bullet)$ & & & & \\
\hline S. perichaetiale & - & - & & & & - & & & & - & & & \\
\hline S. reichardtii & - & - & & & - & & & & & & & & \\
\hline $\begin{array}{l}\text { S. seemanii var. } \\
\text { weberi }\end{array}$ & ? & & & & & & & & & & & & ? \\
\hline S. vitjianum & $\bullet$ & - & & & & - & & & & & & & \\
\hline S. wheeleri & - & & & & & - & & - & & & & & \\
\hline
\end{tabular}




\section{Sphagnum taxa occurring in the Pacific}

*** S. cuspidatum Ehrh. ex Hoffm. PACIFIC: Wijk \& Margadant 1967 as S. capillaceum var. cuspidatum, Wijk \& Margadant 1967 as S. palustre var. cuspidatum, Wijk \& Margadant 1967 as S. capillifolium var. cuspidatum, Wijk \& Margadant 1967. FII: Mitten 1861, Mitten 1873. NWC: Miller et al. 1978, Pursell \& Reese 1982, Whinam \& Hope 2005, Thouvenot \& Bardat 2010. HAW-MA: Miller et al. 1978 rejected previous reports as S. compactum. NOTE: 1) We are not aware of any first hand reports of S. cuspidatum or any of its infrataxa from New Caledonia prior to Miller et al. (1978). 2) We do not know on what Miller et al. (1978) based their statement on the occurrence in Hawaii of S. cuspidatum and we do not think it has ever been recorded from there.

** — subsp. subrecurvum (Warnst.) A.Eddy PACIFIC: Wijk \& Margadant 1967 as S. seemannii. FII: Müller 1874 as S. seemannii ["seemanni"], Warnstorf 1901 as Sphagnum seemannii ["seemanni"], Paul 1924 as S. seemannii, Schultze-Motel 1973a as S. seemannii, Whittier 1975 as S. seemannii, FIJOV: TYPE of S. seemannii, Müller $\mathbf{1 8 7 4}$ as S. seemannii ["seemanni"], Warnstorf 1911 as S. seemannii, Dixon \& Greenwood 1930 as S. seemannii, FIJ-TA: Bartram 1936 as S. seemannii ["seemanii"], Eddy 1977, Miller et al. 1978 as S. seemannii, Whinam \& Hope 2005 as S. seemannii. SAM: Paul 1924 as S. seemannii, Whinam \& Hope 2005 as S. seemannii. NOTE: All reports from Samoa refer to S. seemannii var. weberi that we here exclude from the synonymy of S. cuspidatum (see below). S. cuspidatum should thus be rejected from Samoa until it is clear that this variety also belongs to S. cuspidatum.

* S. leratianum Paris et Warnst. PACIFIC: Wijk \& Margadant 1967. NWC: Paul 1924 ["Le Ratianum"], NWC-SO: TYPE, Brotherus 1911a, Warnstorf 1911 ["Le Ratianum"]. NOTE: This taxon has sometimes been synonymised with S. perichaetiale (Eddy 1977, Crum 1984) and sometimes with S. cristatum (Wijk \& Margadant 1967, Whinam 2003, Whinam \& Hope 2005), possibly following Andrews (1951) who discussed its relationships with other taxa in sect. Sphagnum. We have not studied it, so we recognise it for now, assuming that it will be synonymised when studied further. It is currently only reported from New Caledonia.

*** S. novo-caledoniae Paris et Warnst. PACIFIC: Wijk \& Margadant 1967. NWC: Paul 1924, Miller et al. 1978, Pursell \& Reese 1982, Whinam \& Hope 2005, Thouvenot \& Bardat 2010, NWC-NO: SYNTYPE, Warnstorf 1911, Iwatsuki 1986, NWC-SO: LECTOTYPE, Brotherus 1911a, ["Novae Caledoniae"] Warnstorf 1911, Eddy 1977, Iwatsuki 1986.

Endemic to New Caledonia.

*** S. palustre L. PACIFIC: Wijk \& Margadant 1967 as S. lonchocladum, Wijk \& Margadant 1967 also as S. cymbifolium, S. antarcticum var. $\beta$ lonchocladum, McQueen et Andrus 2006. FI]: Andrews 1951 [with S. vitianum as a synonym], Gangulee 1969, Schultze-Motel 1973 [with S. vitjianum as a synonym], ?Sharp et al. 1994, FIJ-VI: Miller et al. 1978 [with S. vitianum as a synonym], 
Whinam \& Hope 2005. HAW: TYPE of S. lonchocladum, Müller 1896a as S. lonchocladum, Andrews 1951, Schultze-Motel 1962, Gangulee 1969, Crum 1980, Crum 1984, Sharp et al. 1994, Whinam \& Hope 2005, HAW-HA: Bartram 1942, Degener et al. 1969, Hoe 1978, Karlin \& Andrus 1995 also as $S$. henryense Warnst., Staples et al. 2004, Waite 2007, HAW-OA: Miller et al. 1978, Karlin \& Andrus 1995, Karlin 2001 [introduced from Hawaii I. in the 1960's], Waite 2007 ["Introduced as it was used as bedding for forestry seedlings"]. NOTE: 1) All reports from Fiji are due to the inclusion of $S$. vitjianum as a synonym and have to be rejected. 2) S. henryense has been reported from Hawaii, but later rejected as a misidentification of S. palustre (Karlin 2001, Staples et al. 2004, Waite 2007). Recently, Karlin et al. (2010) showed that S. henryense and S. palustre are conspecific using microsatellite data. However, they did not include any specimens from the Pacific area in the analysis. If the Hawaiian material cannot be included in S. palustre s.l., but proves to be a species in its own right, then the correct name would be S. lonchocladum Müll.Hal. (Karlin 2001).

* S. vitjianum Schimp. ex Warnst. PACIFIC: Wijk \& Margadant 1967, FII: TYPE, Warnstorf 1901 ["vitianum"], Paul 1924 ["vitianum"], Dixon \& Greenwood 1930, Whittier 1975, HAW-OA: Hoe 1978. NOTE: 1) S. vitjianum is sometimes treated as a synonym of S. palustre (Andrews 1951) and sometimes of S. perichaetiale (Eddy 1977) and Karlin (2001) mentions that it is "either S. perichaetiale or a closely related species". We prefer to keep it as an accepted taxon until further studies clarify its status. 2) All reports of S. vitjianum from Hawaii are rejected as S. palustre (Karlin \& Andrus 1995, Karlin 2001, Staples et al. 2004). See note under S. palustre. Endemic to Fiji.

** S. wheeleri Müll.Hal. PACIFIC: Wijk \& Margadant 1967 also as S. wheeleri var. vulcanicum, S. rigidulum and S. vulcanicum. HAW: TYPE of S. rigidulum, TYPE, Müller 1887, Warnstorf 1890 as S. rigidulum, Müller 1896a, Warnstorf 1901 also as S. vulcanicum, Paul 1924, HAW-MA: TYPE of S. vulcanicum, Warnstorf 1900 as S. vulcanicum, Degener et al. 1969, Karlin \& Andrus 1995, Karlin 2001, Staples et al. 2004.

Endemic to Hawaii.

\section{Taxa doubtfully occurring in the Pacific}

? S. seemannii Müll.Hal. var. weberi (Warnst.) Warnst. PACIFIC: Wijk \& Margadant 1967 also as S. weberi. SAM: TYPE of S. weberi, Warnstorf 1890 as S. weberi, Schultze-Motel 1973a, Miller et al. 1978. NOTE: S. seemannii is a synonym of S. cuspidatum subsp. subrecurvum (Eddy 1977) but it is unclear what var. weberi is. The type of $S$. weberi was reported from "Samoa, am See 'Draunu' zwischen Gleichenien circa $1400 \mathrm{~m}$ hoch im September 1881 leg. Weber" (Warnstorf 1890) but neither Schultze-Motel (1973a) nor we have been able to find a locality on Samoa that it could come from. In fact, only the island of Savai'i is high enough for the report, but that island does not have any lakes above $1300 \mathrm{~m}$. We have not been able to find where Weber collected in 1881 and 
where there could possibly be a locality like this. However, we are rather sure that it is not on Samoa and would guess that is in New Guinea as both Samoa and part of New Guinea were German colonies at this time.

\section{Taxa rejected from the Pacific}

*** S. compactum Lam. et DC. PACIFIC: Séneca \& Söderström 2009, HAW: Crum 1986, Hill et al. 1992, Fife 1996, HAW-MA: Miller et al. 1978, Crum 1984.

NOTE: Karlin (2001) and Staples et al. (2004) reject all reports from Hawaii as S. wheeleri.

** S. cristatum Hampe NWC: Miller et al. 1978, Whinam \& Hope 2005. NOTE: The only report refers to $S$. leratianum, a taxon sometimes considered a synonym of S. cristatum (Wijk \& Margadant 1967, Whinam 2003, Whinam \& Hope 2005). See note under S. leratianum.

** S. cuspidatum subsp. cuspidatum PACIFIC: Séneca \& Söderström 2009. NOTE: This was erroneously reported as the subspecies instead of the species.

** S. perichaetiale Hampe FIJ: Eddy 1977 [incl. S. vitjianum as a synonym], Seppelt 2006. NWC: Pursell \& Reese 1982, Thouvenot \& Bardat 2010, NWCSO: Eddy 1977 [with S. leratianum as a questioned synonym], Iwatsuki 1986. NOTE: 1) Reports from Fiji are based on S. vitjianum being considerd synonymous with this taxon (Eddy 1977). 2) Reports from New Caledonia are based on S. leratianum being regarded as synonymous (Eddy 1977, Crum 1984). 3) Karlin \& Andrus (1995), Karlin (2001) and Staples et al. (2004) reject all reports from Hawaii, considering them to be $S$. palustre. See also note under S. vitjianum. 4) S. perichaetiale must be rejected from the Pacific until the nomenclature and systematics of this group have been further investigated.

** S. reichardtiiHampeexWarnst.FII:Paul 1924,Dixon \&Greenwood 1930,SchultzeMotel 1973a, Whittier 1975, Miller et al. 1978, FIJ-VI: Whinam \& Hope 2005. NOTE: Warnstorf (1890) included the report of S. acutifolium Ehrh. by Mitten (1873) in his new species S. reichardtii from St. Paul I., in the southern Indian Ocean. The specimen of "S. acutifolium" was collected by G. W. Milne (no. 22) on the expedition to the South Pacific with HMS Herald 1852-1861. The early collection number indicates that it was collected long before reaching the main destination and it is close to other Milne's collection numbers from St. Paul I., so the origin is almost certainly correct. In his Flora Vitiensis Mitten (1873) reported many taxa from places other than Fiji. Several later authors overlooked the locations given by Mitten and assumed them all to be from Fiji. All reports of S. reichardtii from South Pacific are based on this mistake. In addition, Whinam \& Hope (2005) interpreted the word "Viti" in Warnstorf (1891) and Dixon \& Greenwood (1930) as the island of Viti Levu while it is referring to the old name used for the whole Fijian Archipelago, thus erroneously giving it a too precise location. 


\section{Synonyms}

Sphagnum antarcticum var. $\equiv$ lonchocladum (Müll.Hal.) Warnst. $=$ S. palustre

Sphagnum capillaceum var. cuspidatum (Ehrh. ex Hoffm.) Wahlenb. = S. cuspidatum

Sphagnum capillifolium var. cuspidatum (Ehrh. ex Hoffm.) Brid. = S. cuspidatum

Sphagnum cymbifolium (Ehrh.) Hedw. nom. inval. $=$ S. palustre

Sphagnum henryense Warnst. $=$ S. palustre

Sphagnum lonchocladum Müll.Hal. = S. palustre

Sphagnum palustre var. cuspidatum (Ehrh. ex Hoffm.) Lilj. = S. cuspidatum

Sphagnum rigidulum Warnst. $=$ S. wheeleri

Sphagnum seemannii Müll.Hal. $=$ S. cuspidatum subsp. subrecurvum

Sphagnum vulcanicum Warnst. $=S$. wheeleri

Sphagnum weberi Warnst. $\equiv$ S. seemannii var. weberi

Sphagnum wheeleri var. vulcanicum (Warnst.) Warnst. = S. wheeleri

\section{Acknowledgment}

We are grateful to Anders Hagborg for useful comments on the manuscript.

\section{References}

Andrews AL (1951) Studies in the Warnstorf Sphagnum herbarium. VI. The subgenus Inophloea in the eastern hemisphere. The Bryologist 54: 83-91.

Bartram EB (1936) Contribution to the mosses of Fiji. Occasional Papers of Bernice Pauahi Bishop Museum of Polynesian Ethnology and Natural History XI (20): 1-30.

Bartram EB (1942) Mosses collected by the Hawaiian bog survey of 1938. Occasional Papers of Bernice Pauahi Bishop Museum of Polynesian Ethnology and Natural History XVI(14): 321336.

Brotherus VF (1911) Contribution à la flore bryologique de la Nouvelle Calédonie. III. Öfversigt af Finska Vetenskaps-Societetens Förhandlingar 53A (11): 1-43.

Brummitt RK (2001) World geographical scheme for recording plant distributions. Ed. 2, (TDWG, Hunts Inst. Bot. Doc.: Pittsburgh)

Crum HA (1980) A guide to the identification of Mexican Sphagna. Contributions from the university of Michigan herbarium 14: 25-52.

Crum HA (1984) Sphagnopsida. Sphagnaceae. North American Flora 11: 1-180.

Crum HA (1986) Illustrated Moss Flora of Arctic North America and Greenland. 2. Sphagnaceae. BioScience 18: 1-61.

Degener O, Degener I, Hörmann H (1969) Cynea carlsonii and the unnatural distribution of Sphagnum palustre L. Phytologia 19: 1-3.

Dixon HN \& Greenwood W (1930) The mosses of Fiji. Proceedings of the Linnean Society of New South Wales 55: 261-302.

Eddy A (1977) Sphagnales of Tropical Asia. Bulletin of the British Museum (natural history), botany 5: 359-445.

Fife AJ (1996) A synopsis of New Zealand Sphagna, with a description of S. simplex sp. nov. New Zealand journal of botany 34: 309-328.

Gangulee HC (1969) Mosses of eastern India and adjacent regions. Fascicle 1 Sphagnideae, Andreaeideae \& Nematodonteae. (Calcutta).

Hill MO, Preston CD \& Smith AJE (1992) Atlas of the Bryophytes of Britain and Ireland. Volume 2 Mosses (except Diplolepideae). (Harley Books: Colchester). 
Hoe WJ (1978) Bryophyta Hawaiica Exsiccata — The first Century. The Bryologist 81: 411-415. Iwatsuki Z (1986) A peculiar New Caledonian Sphagnum with rhizoids. The Bryologist 89: 20-22. Karlin EF (2001) Taxonomy of Hawaiian Sphagna. The Bryologist 104: 290-296.

Karlin EF \& Andrus RE (1995) The Sphagna of Hawaii. The Bryologist 98: 235-238.

Karlin EF, Giusti MM, Lake RA, Boles SB \& Shaw AJ 2010 Microsatellite analysis of Sphagnum centrale, S. henryense and S. palustre (Sphagnaceae). The Bryologist 113: 90-98.

McQueen CB \& Andrus RE (2006) Bryophyte Flora of North America.1. Introduction, Acrocarpous Mosses. Flora of North America, Missouri Botanical Garden 27: 1-65.

Miller HA, Whittier HO \& Whittier BA (1978) Prodromus florae muscorum Polynesiae. Bryophytorum Bibliotheca 16: 1-334.

Mitten W (1861) Musci et Hepaticae Vitiensis. Bonplandia 9: 365-367.

Mitten W (1873) Musci, Jungermanniae and Marchantiae. Pp. 325-453 in Seemann B (ed.), Flora vitiensis. (Reeve: London).

Müller C (1874) Musci polynaesiae praesertim Vitiani et Samoani Graeffeani. Journal of the Museum Godeffroy 3(6): 51-90.

Müller C (1887) Sphagnorum novorum descriptio. Flora 70: 403-422.

Paul H (1924) Sphagnaceae (Torfmoose). Pp. 105-125 in Engler A (ed.), Die natürlichen Pflanzenfamilien, vol. 10, heft 1. (Wilhem Engelmann: Leipzig).

Pursell RA \& Reese WD (1982) The mosses reported from New Caledonia. Journal of the Hattori botanical laboratory 53: 449-482.

Schabetsberger R, Drozdowski G, Rott E, Lenzenweger R, Jersabek CD, Fiers F, Traunspurger W, Reiff N, Stoch F, Kotov AA, Martens K, Schatz H \& Kaiser R (2009) Losing the Bounty? Investigating Species Richness in Isolated Freshwater Ecosystems of Oceania. Pacific Science 63:153-179

Schultze-Motel W (1962) Beitrag zur Kenntniss der Laubmoose der Hawaii-Inseln. Willdenowia. 3: $97-107$.

Schultze-Motel W (1973a) Katalog der Laubmoose von Melanesien. Willdenowia 7: 47-82.

Schultze-Motel W (1973b) Taxonomische Studien an samoanischen Laubmoosen. Revue Bryologique et Lichénologique 39: 245-252.

Séneca A \& Söderström L (2009) Sphagnophyta of Europe and Macaronesia: a checklist with distribution data. Journal of Bryology 31: 243-254.

Seppelt R D (2006) Mosses. 1. Pp 89-107 in McCarthy PM (ed.), Flora of Australia Vol. 51. (Australian Biological Resources Study: Canberra).

Sharp AJ, Crum H \& Eckel PM (1994) The moss flora of Mexico. Memoirs of the New York botanical garden 69: 1-1113.

Staples GW, Imada CT, Hoe WJ \& Smith CW (2004) A revised checklist of Hawaiian mosses. Tropical Bryology 25: 35-70.

Thouvenot L \& Bardat J (2010) Liste actualisée et annotée des mousses de Nouvelle-Calédonie. Cryptogamie, Bryologie 31: 163-197.

von Konrat M, Söderström L \& Hagborg A (2010) The Early Land Plants Today project: A community-driven effort and a new partnership with Phytotaxa. Phytotaxa 9: 11-21.

von Konrat M, Naikatini A, Tuiwawa M, Söderström L, Fife A, Renner M, Brownsey P, Perrie L, Hagborg A, Pócs T, Lumbsch HT, Braggins J, Séneca A \& Brown E (2011) A brief history of the cryptogams of Fiji and prospects for the future. Telopea 13: 361-374.

Waite M (2007) Mosses of Hawaii Volcanoes National Park. University of Hawai'i at Mānoa, Technical Report 153: 1-55.

Warnstorf C (1890) Beiträge zur Kenntniss exotischer Sphagna. Hedwigia 29: 213-258.

Warnstorf C (1891) Beiträge zur Kenntniss exotischer Sphagna. Hedwigia 30: 127-178.

Warnstorf C (1900) Weitere Beiträge zur Kenntniss der Torfmoose. Botanisches Centralblatt 21 (82): 7-14.

Warnstorf C (1901) Sphagnaceae (Torfmoose). Pp. 248-262 in Engler A (ed.), Die natürlichen Pflanzenfamilien, I. Teil, Abt. 3 (Wilhem Engelmann: Leipzig). 
Warnstorf C (1911) Sphagnales - Sphagnaceae (Sphagnologia Universalis). Pp. 1-546 in Engler A (ed.), Das Pflanzenreich. Regni vegetabilis conspectus 51. (Wilhem Engelman: Leipzig).

Whinam J, Hope GS, Clarkson BR, Buxton RP, Alspach PA \& Adam P (2003) Sphagnum in peatlands of Australasia: Their distribution, utilisation and management. Wetlands Ecology and Management 11:37-49.

Whinam J \& Hope G (2005) Sphagnum peatlands of Australasia. Denisia 2: 1-38.

Whittier HO (1973) Mosses of the Marquesas Islands, French Polynesia. The Bryologist 76: 174177

Whittier HO (1975) A preliminary list of Fijian mosses. Florida Scientist 38(2): 85-106.

Wijk R \& Margadant W (1967) Index Muscorum.4. (Utrecht).

Manuscript received 10 January 2011, accepted 18 August 2011 